\begin{tabular}{|c|l|}
\hline Title & Debt structure and capital structure : based on bank debt renegotiation \\
\hline Sub Title & \\
\hline Author & $\begin{array}{l}\text { 富田, 信太郎(Tomita, Shintaro) } \\
\text { 池田, 直史(Ikeda, Naoshi) } \\
\text { 辻, 幸民(Tsuji, Yukitami) }\end{array}$ \\
\hline Publisher & Society of Business and Commerce, Keio University \\
\hline Publication year & 2015 \\
\hline Jtitle & Keio business review No.50(2015),p.1(1)- 24(24) \\
\hline JaLC DOI & \\
\hline Abstract & $\begin{array}{l}\text { This paper proposes a model that determines optimal capital and debt structure when a firm } \\
\text { uses two types of debt; a bank debt and a bond. Their difference lies in whether a firm can } \\
\text { renegotiate with a creditor or not. Renegotiation with bondholders seems to be hard because } \\
\text { bonds are dispersively held by many bondholders. So we assume that interest payments to the } \\
\text { bank debt can be reduced by the renegotiation when the firm goes worse but those to the } \\
\text { bondholders cannot. Benefit of the renegotiation makes the bank debt more favorable. However, } \\
\text { since the bank debt accompanies its additional costs, taking account of these trade-off, the firm } \\
\text { decides optimal composition of equity, a bank debt, and a bond. }\end{array}$ \\
\hline Notes & \\
\hline Genre & Journal Article \\
\hline URL & $\begin{array}{l}\text { https://koara.lib.keio.ac.jp/xoonips/modules/xoonips/detail.php?koara_id=AA00260481-2015000 } \\
\text { 0-0001 }\end{array}$ \\
\hline
\end{tabular}

慶應義塾大学学術情報リポジトリ(KOARA)に掲載されているコンテンツの著作権は、それぞれの著作者、学会または出版社/発行者に帰属し、その権利は著作権法によって 保護されています。引用にあたっては、著作権法を遵守してご利用ください。

The copyrights of content available on the KeiO Associated Repository of Academic resources (KOARA) belong to the respective authors, academic societies, or publishers/issuers, and these rights are protected by the Japanese Copyright Act. When quoting the content, please follow the Japanese copyright act. 


\title{
Debt Structure and Capital Structure: Based on Bank Debt Renegotiation*
}

\author{
By \\ Shintaro Tomita ${ }^{\dagger}$ \\ Naoshi Ikeda ${ }^{\ddagger}$ \\ Yukitami Tsuji ${ }^{\S}$
}

\begin{abstract}
This paper proposes a model that determines optimal capital and debt structure when a firm uses two types of debt; a bank debt and a bond. Their difference lies in whether a firm can renegotiate with a creditor or not. Renegotiation with bondholders seems to be hard because bonds are dispersively held by many bondholders. So we assume that interest payments to the bank debt can be reduced by the renegotiation when the firm goes worse but those to the bondholders cannot. Benefit of the renegotiation makes the bank debt more favorable. However, since the bank debt accompanies its additional costs, taking account of these trade-off, the firm decides optimal composition of equity, a bank debt, and a bond.
\end{abstract}

\section{Key Words}

Debt structure, Capital structure, Bank debt, Nash bargaining

\section{Introduction}

How firms finance their projects is essential in corporate finance. In particular, many economists have studied how firms make decisions about corporate capital structure, and constructed various models that endogenously determined the optimal amount of debt in capital structure. Among them, the most representative is the trade-off theory, which derives it from balancing tax shields and bankruptcy costs, and on which various refinements have been made

\footnotetext{
*This paper is the revised version of "Debt Structure and Capital Structure: Based on Bank Debt Renegotiation (in Japanese)," published on Review of Monetary and Financial Studies, Vol.37 (2015), pp.19-40. The authors are grateful to S. Tamura, T. Kaneko, K. Wada, N. Teshima, T. Takahashi, M. Sakuragawa, and the anonymous referee of RMFS. Section 4 of this paper is an attached description.

${ }^{\dagger}$ Keio University, Faculty of Business and Commerce

${ }^{\ddagger}$ Tokyo Institute of Technology, Department of Industrial Engineering and Management

$\S$ Keio University, Faculty of Business and Commerce
} 
until now.

The theory of capital structure including the trade-off models discusses the structure of debt and equity. However, most of them are silent on how a firm determines the detail of debt, what is called debt structure. The fact that large companies in the US, where corporate bond markets have been developed, commonly issue bonds for long-term debt may avoid the necessity of discussing the debt structure. In this study, we propose a capital structure model which, explicitly considering a difference between a bank debt and a bond, determines the capital structure and the debt structure simultaneously in the traditional trade-off framework.

Intuitively, there are various differences between a bank debt and a bond. Among them, we focus on the possibility of renegotiation in a situation where a firm is about to go bankrupt. It is often said that the bank debt is easily renegotiable because a few creditors are concerned with it. If firm's manager intends to renegotiate about the bank debt, all he/she should do is to go to the bank, and renegotiating is not very costly. On the other hand, when creditors disperse, renegotiating with them might be difficult owing to the existence of a free-rider problem. So it may be too costly for a firm to renegotiate about bonds. Our model in this study derives the optimal capital and debt structure simultaneously from this difference.

Another characteristic of this study is that we use a continuous time model. These days the trade-off theory has been refined variously in corporate finance, and a lot of models based on continuous time have been developed in the asset pricing theory. A pioneer who proposed a capital structure model on continuous time is Leland (1994). Thereafter, a number of continuous time capital structure models have been presented as extensions of Leland (1994). ${ }^{1}$

Although there are many studies for capital structure, it is surprising that few studies consider different kinds of debt. Hacbarth-Hennessy-Leland (2007) (hereafter, HHL) is almost only one that simultaneously includes the capital structure and the debt structure in a continuous time model. Among continuous time models for capital structure, there are other studies which assume renegotiable debt though they do not consider the mix of different debt; MellaBarralPerraudin (1997) and Fan-Sundaresan (2000) (hereafter, FS). These develop a capital structure model when debt is renegotiable.

In this study, we propose a capital structure model which can determine the debt structure, extending FS. FS's model assumes the Nash Bargaining at the renegotiation. Models of HHL and MellaBarral-Perraudin depend on the Take-it-or-Leave-it negotiation, where a firm takes all the power of the negotiation. However, in FS model, the negotiation power is distributed between a firm and creditors, and then the two parties share benefits of the renegotiation, following the Nash Bargaining solution. When considering a renegotiable bank debt and an unrenegotiable bond at the same time, our model analyzes how the mix of equity, a bank debt, and a bond is determined optimally in the framework of the Nash Bargaining.

The basic idea of our model is as follows. When a firm uses debt, it takes advantage of the tax shield and suffers from the probability of bankruptcy. Because bankruptcy accompanies its costs, the use of debt increases expected costs of bankruptcy. A firm employs two types of debt, which are a bank debt and a bond. With the bank debt, renegotiation with the bank remits interest payments to the bank before bankruptcy occurs. We assume that a unique state variable is firm's asset value. If the asset value decreases and reaches a certain level, the

\footnotetext{
${ }^{1}$ There are many studies of capital structure using continuous time models. The earliest are Black-Scholes (1973) or Black-Cox (1976). Leland (1994) modeled his optimal capital structure, and then a lot of studies have developed his model. For example, see Leland-Toft (1996), MellaBarral-Perraudin (1997), Leland (1998), MellaBarral (1999), Fan-Sundaresan (2000), Goldstein-Ju-Leland (2001), Morellec (2004), Ju-Parrino-Poteshman-Weisbach (2005), ParrinoPoteshman-Weisbach (2005), Hackbarth-Miao-Morellec (2006), and Hackbarth-Hennessy-Leland (2007).
} 
renegotiation starts. We designate the level at which the renegotiation occurs as a "renegotiation point." In the renegotiation, shareholders and the bank make a Nash Bargaining game and share a continuation value if the firm is alive. Since it is impossible to renegotiate with bondholders, the continuation value in the renegotiation amounts to subtracting a bond value from firm's asset value. Furthermore, when the asset value deteriorates more and reaches a certain level, the firm goes bankrupt. The level that triggers the bankruptcy is designated as a "bankruptcy point."

A characteristic of our model is that introducing the renegotiation enables to decide the optimal composition of equity, a bank debt, and a bond. HHL's model also determines the mix of them, but the optimum of their model is a corner solution. This is because the bankruptcy point is independent of the use of the bank debt. Since they assume the Take-it-or-Leave-it renegotiation, shareholders take all benefit of the renegotiation. Unless the bank debt affects the bankruptcy point, the bank debt takes only advantage of the tax shields without accompanying the expected bankruptcy costs. Therefore, it is optimal for the firm to employ the bank debt as much as possible.

Our model is different from HHL's in that the renegotiation depends on the Nash Bargaining. From the Nash Bargaining renegotiation, where a bank as well as shareholders has a share of the benefit, the bankruptcy point is not independent of the use of bank debt. As the result, the amount of the bank debt affects the bankruptcy point. Although the renegotiation makes the bank debt more favorable than the bond in terms of the trade-off between the tax shield and the expected bankruptcy costs, it does not benefit only the bank. The bank debt renegotiation decreases the bankruptcy point, which means that bankruptcy is postponed. It also makes a bond value rise because the bondholders get a free ride on firm's continuation. A firm takes these effects into account and decides the optimal capital and debt structure.

Although the Nash Bargaining makes it possible to derive it as an inner solution, the optimal debt structure depends much on the bank debt. This reflects the fact that the renegotiation benefit exists more in the bank debt than in the bond because the bank is a participant of the renegotiation. On the other hand, past studies about a bank debt maintain that it also has negative aspects (e.g., Bolton-Freixas 2000, Detragiache 1994, Rajan 1992). If the positive aspect of the renegotiation is included, then negative aspects of the bank debt should be taken into account. Our model assumes that the use of the bank debt incurs extra costs besides interest payments. Considering the trade-off between them, a firm decides the capital and debt structure optimally. Introducing the additional costs enables our model to generate the debt structure that seems enough to be realistic.

This paper is organized as follows. Section 2 formulates our model. We describe how the optimal capital structure and the optimal debt structure are determined when the firm can use two types of debt. In Section 3, the model is numerically calculated, and simulation shows how the optimal structure changes in response to a change in parameters. We modify an assumption of the model in Section 4 and examine how the outcome of the model changes. Section 5 provides concluding remarks.

\section{Model}

The value of assets a firm holds, $A_{t}$, is the only state variable of this model. The assets are assumed to be tradable, so $A_{t}$ is regarded as a security price that follows such a process as 


$$
d A_{t}=(\mu-\beta) A_{t} d t+v A_{t} d Z_{t}
$$

where $\beta A_{t}$ is a cash flow generated from the assets and distributed to investors, and $\beta$ is a constant. $A_{t}$ is also considered as an unlevered firm value. $Z_{t}$ is the Wiener process.

A firm issues two kinds of debt; one is a bank debt and the other is a bond. Suppose that both of them are claims of the consols type. Interest payments to the bank debt and the bond are $b$ and $c$ respectively, and these are paid continuously. The difference in the two kinds of debt is that the bank debt is renegotiable but the bond is not. We assume that bankruptcy occurs when the asset value $A_{t}$ goes down to a bankruptcy point, $A_{B}$. The firm can renegotiate with the bank and cut out the bank debt interest before it goes bankrupt. The renegotiation starts when $A_{t}$ falls bellow a renegotiation point, $A_{S}$.

When the state variable $A_{t}$ reaches $A_{B}$, the firm defaults and is liquidated. Liquidation incurs bankruptcy costs, which amounts to $k A_{B}$, so creditors receive $(1-k) A_{B}$. We assume that a fraction $\alpha$ of the liquidation value is distributed to the bondholders and $(1-\alpha)$ to the bank. In the bankruptcy, shareholders get nothing.

It is practical to consider that the liquidation value is distributed in proportion to the amount each creditor claims. For example, there are two creditors; one creditor claims $\$ 100$ and the other claims $\$ 1000$. In this case, the distribution of the liquidation value is in the ratio, 1:10. Realistically, negotiation power of creditors may affect the distribution. But we neglect it for brevity and assume that the liquidation value distributed is proportional to interest payments debt promises. In other words, $\alpha=c /(b+c)$ holds.

When the asset value $A_{t}$ falls to $A_{S}$, renegotiation starts. How should shareholders and a bank negotiate about their portions of the firm? Here the Nash Bargaining is assumed to decide it.

Renegotiation between the shareholders and the bank means that the firm refuses to pay the promised interest $b+c$. If debt were not renegotiable, refusing it would bring about bankruptcy immediately. Hence, they have to compare their portions when the renegotiation succeeds in remission from the payment and those when unsuccessful renegotiation ends up with the bankruptcy. By the way, this model assumes that the firm continues paying interest to bondholders in the middle of the renegotiation because the firm cannot renegotiate with them. We denote values of the firm and the bond by $V\left(A_{t}\right)$ and $C\left(A_{t}\right)$. At the renegotiation, $\left\{V\left(A_{t}\right)-C\left(A_{t}\right)\right\}$ is divided between the shareholders and the bank. Defining $\theta$ as the proportion of the shareholders, the claims of the shareholders and the bank are expressed as $\theta\left\{V\left(A_{t}\right)-C\left(A_{t}\right)\right\}$ and $(1-\theta)\left\{V\left(A_{t}\right)-C\left(A_{t}\right)\right\}$ respectively when the renegotiation succeeds. If the renegotiation fails, liquidation occurs, and then the bondholders and the bank share the liquidation value in the proportion of $\alpha:(1-\alpha)$. Therefore, the shareholders, the bank, and the bondholders get values of $0,(1-\alpha)(1-k) A_{t}$, and $\alpha(1-k) A_{t}$ respectively.

Comparing between the successful and unsuccessful cases, the renegotiation increases the value the shareholders and the bank can get by $\theta\left\{V\left(A_{t}\right)-C\left(A_{t}\right)\right\}-0$ and $(1-\theta)\left\{V\left(A_{t}\right)-\right.$ $\left.C\left(A_{t}\right)\right\}-(1-\alpha)(1-k) A_{t}$. Assume that $\eta$ is negotiation power of the shareholders at the renegotiation, so bank's is $(1-\eta)$. Considering the Nash Bargaining, $\theta^{*}$ is solved from

$$
\theta^{*}=\arg \max _{\theta}\left[\theta\left\{V\left(A_{t}\right)-C\left(A_{t}\right)\right\}\right]^{\eta}\left[(1-\theta)\left\{V\left(A_{t}\right)-C\left(A_{t}\right)\right\}-(1-\alpha)(1-k) A_{t}\right]^{(1-\eta)} .
$$

This first order condition shows

$$
\theta^{*}=\eta-\eta \frac{(1-\alpha)(1-k) A_{t}}{V\left(A_{t}\right)-C\left(A_{t}\right)}
$$


This is the optimal proportion in terms of the Nash Bargaining. During the renegotiation, each stakeholder is distributed in the proportion calculated by Equation (1).

\subsection{Valuation of Securities}

The value of a security depends on the state variable. When the security pays instantaneous cash flows of $f\left(A_{t}\right)$, it is valuated as $F\left(A_{t}\right)$, which satisfies an equilibrium condition as follows:

$$
\frac{\partial F\left(A_{t}\right)}{\partial A_{t}}(r-\beta) A_{t}+\frac{1}{2} \frac{\partial^{2} F\left(A_{t}\right)}{\partial A_{t}^{2}} v^{2} A_{t}^{2}-r F\left(A_{t}\right)+f\left(A_{t}\right)=0 .
$$

This is a normal Euler's differential equation. In the case of $f\left(A_{t}\right)=m_{1} A_{t}+m_{2}$, where $m_{1}$ and $m_{2}$ are constants, its general solution is written as

$$
\begin{gathered}
F\left(A_{t}\right)=\frac{m_{1} A_{t}}{\beta}+\frac{m_{2}}{r}+D_{1} A_{t}^{x}+D_{2} A_{t}^{y}, \\
x \equiv \frac{1}{2}-\frac{r-\beta}{v^{2}}+\sqrt{\left(\frac{r-\beta}{v^{2}}-\frac{1}{2}\right)^{2}+\frac{2 r}{v^{2}}}>0, \\
y \equiv \frac{1}{2}-\frac{r-\beta}{v^{2}}-\sqrt{\left(\frac{r-\beta}{v^{2}}-\frac{1}{2}\right)^{2}+\frac{2 r}{v^{2}}}<0,
\end{gathered}
$$

where $D_{1}$ and $D_{2}$ are arbitrary constants and derived from appropriate boundary conditions.

Here, security values of this model are formulated. What the shareholders and the bank can obtain as the result of renegotiation depends on values of the firm and the bond. First of all, we calculate the firm value. The cash flow that the firm pays to overall investors is $\beta A_{t}+\tau(b+c)$ in the case of $A_{t}>A_{s} . \tau(b+c)$ is a tax shield of the debt. We assume that the tax shield disappears in the region of renegotiation, so the cash flow is $\beta A_{t}$ in the case of $A_{S} \geq A_{t}>A_{B} .^{2}$

Considering Equation (2), the firm value $V\left(A_{t}\right)$ is formulated as follows. Since the function of $V\left(A_{t}\right)$ depends on the cash flow, $V\left(A_{t}\right)$ is designated as $V_{H}\left(A_{t}\right)$ for $A_{t}>A_{S}$ and as $V_{L}\left(A_{t}\right)$ for $A_{S} \geq A_{t}>A_{B}$.

$$
\begin{aligned}
& V_{H}\left(A_{t}\right)=A_{t}+\frac{\tau(b+c)}{r}+G_{1} A_{t}^{x}+G_{2} A_{t}^{y} \quad \text { if } A_{t}>A_{S}, \\
& V_{L}\left(A_{t}\right)=A_{t}+G_{3} A_{t}^{x}+G_{4} A_{t}^{y} \quad \text { if } A_{S} \geq A_{t} \geq A_{B},
\end{aligned}
$$

where four arbitrary constants, $G_{1}, G_{2}, G_{3}$, and $G_{4}$, are specified by following four boundary conditions.

$$
\begin{aligned}
V_{H}\left(A_{t}\right) & =A_{t}+\frac{\tau(b+c)}{r} \quad \text { if } A_{t} \gg A_{S} \\
\lim _{A_{t} \downarrow A_{S}} V_{H}\left(A_{t}\right) & =\lim _{A_{t} \uparrow A_{S}} V_{L}\left(A_{t}\right) \\
\lim _{A_{t} \downarrow A_{B}} V_{L}\left(A_{t}\right) & =(1-k) A_{B}
\end{aligned}
$$

\footnotetext{
${ }^{2}$ The assumption that the firm loses the tax shield in the renegotiation region is also employed by Fan-Sundaresan (2000). In reality, in such a situation that it must renegotiate with a bank, a firm earns no profits, and no tax shield occurs because it does not pay taxes but debt interest. In this model, although a cash flow is generated in the region of renegotiation, we can consider it to be generated by sales of firm's assets rather than by profits.
} 


$$
\lim _{A_{t} \downarrow A_{S}} \frac{\partial V_{H}\left(A_{t}\right)}{\partial A_{t}}=\lim _{A_{t} \uparrow A_{S}} \frac{\partial V_{L}\left(A_{t}\right)}{\partial A_{t}}
$$

The first condition is that, for sufficiently large $A_{t}$, the firm value is regarded as a perpetuity that pays cash flows of $\beta A_{t}+\tau(b+c)$ permanently. The second and the third are value matching conditions concerning $A_{S}$ and $A_{B}$. The last is a smooth pasting condition, which makes $V_{H}\left(A_{t}\right)$ and $V_{L}\left(A_{t}\right)$ connecting smoothly around the renegotiation point $A_{S} .{ }^{3}$ From these boundary conditions, we obtain the firm values, $V_{H}\left(A_{t}\right)$ and $V_{L}\left(A_{t}\right){ }^{4}$

Since the distribution at the renegotiation is also affected by a bond value, it affects bank debt and equity values. The value of the bond is formulated in the same way as the firm value. Bond valuation is specified by boundary conditions concerning it.

A bond generates a constant cash flow as long as $A_{t}$ is above the bankruptcy point $A_{B}$, because bondholders cannot renegotiate. Thus, a general solution is written as

$$
C\left(A_{t}\right)=\frac{c}{r}+H_{1} A_{t}^{x}+H_{2} A_{t}^{y} \quad \text { if } A_{t}>A_{B},
$$

where boundary conditions that decide arbitrary constants, $H_{1}$ and $H_{2}$, are

$$
\begin{aligned}
C\left(A_{t}\right) & =\frac{c}{r} \quad \text { if } A_{t} \gg A_{B}, \\
\lim _{A_{t} \downarrow A_{B}} C\left(A_{t}\right) & =\alpha(1-k) A_{B} .
\end{aligned}
$$

The first equation explains that, for sufficiently large $A_{t}$, the bond becomes a perpetuity that pays interest $c$ permanently. The second is a value matching condition at the point of $A_{B}$. The bond value is derived from these conditions.

Given the values of the firm and the bond, the bank debt can be evaluated. In the renegotiation region, interest paid to the bank is dependent on $A_{t}$ and denoted as $\hat{s}\left(A_{t}\right)$. Cash flows to the bank are $b$ for $A_{t}>A_{S}$ and $\hat{s}\left(A_{t}\right)$ for $A_{S} \geq A_{t}>A_{B}$. The function of $\hat{s}\left(A_{t}\right)$ is demonstrated afterwards. Corresponding to $A_{t}$, a bank debt value $B\left(A_{t}\right)$ has two functions; $B_{H}\left(A_{t}\right)$ for $A_{t}>A_{S}$ and $B_{L}\left(A_{t}\right)$ for $A_{S} \geq A_{t}>A_{B}$.

We consider the case of $A_{t}>A_{S}$ first. Then the bank gets the cash flow of $b$, so the value of the bank debt is expressed as

$$
B_{H}\left(A_{t}\right)=\frac{b}{r}+L_{1} A_{t}^{x}+L_{2} A_{t}^{y} \quad \text { if } A_{t}>A_{S} .
$$

Boundary conditions for arbitrary constants are

$$
\begin{aligned}
B_{H}\left(A_{t}\right) & =\frac{b}{r} \quad \text { if } A_{t} \gg A_{S}, \\
\lim _{A_{t} \downarrow A_{S}} B_{H}\left(A_{t}\right) & =\left(1-\theta^{*}\right)\left\{V\left(A_{S}\right)-C\left(A_{S}\right)\right\} .
\end{aligned}
$$

The first equation is the same as the bond. When the asset value is sufficiently large, the bank debt becomes a perpetuity that pays $b$ permanently. The second is a value matching condition. When $A_{S} \geq A_{t} \geq A_{B}$, using Equation (1), the bank debt value must be $B_{L}\left(A_{t}\right)=$ $\left(1-\theta^{*}\right)\left\{V\left(A_{t}\right)-C\left(A_{t}\right)\right\}$. Thus, the value matching condition is formulated as Equation (5).

\footnotetext{
${ }^{3}$ Considering arbitrage using a transition point of a cash flow, this condition must be satisfied for no-arbitrage. See Dixit (1993) for detailed arguments.

${ }^{4}$ See Appendix for detailed solutions of the firm and other security values.
} 
Next, the case of $A_{S} \geq A_{t} \geq A_{B}$ is investigated. As the result of the renegotiation, the bank debt must satisfy $B_{L}\left(A_{t}\right)=\left(1-\theta^{*}\right)\left\{V\left(A_{t}\right)-C\left(A_{t}\right)\right\}$. At the same time, the payment to the bank, $\hat{s}\left(A_{t}\right)$, must satisfy the equilibrium condition. That is

$$
\frac{\partial B_{L}\left(A_{t}\right)}{\partial A_{t}}(r-\beta) A_{t}+\frac{1}{2} \frac{\partial^{2} B_{L}\left(A_{t}\right)}{\partial A_{t}^{2}} v^{2} A_{t}^{2}-r B_{L}\left(A_{t}\right)+\hat{s}\left(A_{t}\right)=0 \quad \text { if } A_{S} \geq A_{t} \geq A_{B} .
$$

$\hat{s}\left(A_{t}\right)$ is computed by substituting $B_{L}\left(A_{t}\right)=\left(1-\theta^{*}\right)\left\{V\left(A_{t}\right)-C\left(A_{t}\right)\right\}$ into this equation. Since the bank debt is a security, its value also satisfies the equilibrium condition. The Nash Bargaining has already set the bank debt value. So we have to formulate the function $\hat{s}\left(A_{t}\right)$ in order that the bank debt value holds the equilibrium.

The last is equity valuation. As well as the bank debt, the equity value $S\left(A_{t}\right)$ depends on the state variable. $S\left(A_{t}\right)$ is designated as $S_{H}\left(A_{t}\right)$ for $A_{t}>A_{S}$ and as $S_{L}\left(A_{t}\right)$ for $A_{S} \geq A_{t} \geq A_{B}$. In the renegotiation region, the equity value is $S_{L}\left(A_{t}\right)=\theta^{*}\left\{V\left(A_{t}\right)-C\left(A_{t}\right)\right\}$ as the result of renegotiation. Substituting the values of the firm and the bond leads to the equity value.

On the other hand, for $A_{t}>A_{S}$, a cash flow to shareholders includes not only what firm's assets generate, but also the tax shield effect of the interest payments. Hence, the cash flow to the shareholders in the no renegotiation region is $\beta A_{t}-(1-\tau)(b+c)$. The equity is evaluated as

$$
S_{H}\left(A_{t}\right)=A_{t}-\frac{(1-\tau)(b+c)}{r}+J_{1} A_{t}^{x}+J_{2} A_{t}^{y} \quad \text { if } A_{t}>A_{S} .
$$

Two boundary conditions below decide arbitrary constants.

$$
\begin{aligned}
S_{H}\left(A_{t}\right) & =A_{t}-\frac{(1-\tau)(b+c)}{r} \quad \text { if } A_{t} \gg A_{S}, \\
\lim _{A_{t} \downarrow A_{S}} S_{H}\left(A_{t}\right) & =\theta^{*}\left\{V\left(A_{S}\right)-C\left(A_{S}\right)\right\} .
\end{aligned}
$$

From these equations, $S_{H}\left(A_{t}\right)$ is calculated. Equity values, $S_{H}$ and $S_{L}$, are obtained just as the bank debt values are derived. We show these specific formulas in Appendix.

\subsection{Bankruptcy Point, Renegotiation Point, and Optimal Capital Structure}

It is common in most studies that the renegotiation point and the bankruptcy point are calculated from maximization of an equity value. This is denoted as a smooth pasting condition. ${ }^{5}$ $A_{S}$ and $A_{B}$ are decided from

$$
\begin{aligned}
& \frac{\partial S_{H}}{\partial A_{S}}=0, \\
& \frac{\partial S_{L}}{\partial A_{B}}=0 .
\end{aligned}
$$

If shareholders are able to set these points without any restriction, the renegotiation and bankruptcy points are chosen through maximizing the equity value. We suppose that the shareholders make a rational decision about $A_{S}$ and $A_{B} \cdot{ }^{6}$

Once the renegotiation and bankruptcy points are given, the values of the firm and other securities are functions of interest payments promised to creditors. Thus, we calculate interest

\footnotetext{
${ }^{5}$ This paper models security valuation with $A_{B}$ and $A_{S}$ given. Irrespective of how to decide them, the value of a security is computed once $A_{B}$ and $A_{S}$ are valuated.

${ }^{6}$ Equations (6) and (7) make up a non-linear simultaneous equation system that $A_{S}$ and $A_{B}$ satisfy. See Appendix for detail.
} 
payments, $b$ and $c$, that maximize the firm value at time $t=0$ so as to achieve the optimal capital and debt structure.

$$
\begin{aligned}
& \frac{\partial V\left(A_{0}\right)}{\partial b}=0 \\
& \frac{\partial V\left(A_{0}\right)}{\partial c}=0
\end{aligned}
$$

$b^{*}$ and $c^{*}$ computed from these conditions are the optimal interest payments, and substituting them into the valuation equations brings about the optimal value of each security.

\subsection{A Numerical Example and Additional Bank Debt Costs}

Our model focuses on the renegotiation of a bank debt. The difference between the bank debt and a bond is that only the former is renegotiable. What is a characteristic of this model in terms of firm's optimal decision-making? In this section, giving some parameters, we analyze the model by calculating simulation.

\subsubsection{The Case of A Basic Model}

Table 1 shows a numerical result when some parameters are exogenously set. These parameters are an initial asset value $A_{0}$, a corporate tax rate $\tau$, the proportion of bankruptcy costs $k$, volatility of the asset value $v$, a riskless rate $r$, the negotiation power of shareholders $\eta$, a cash flow ratio from the asset $\beta$. When a firm goes bankrupt, we assume that a bank and bond creditors share firm's liquidation value in the proportion of promised interest payments. A distribution ratio in the liquidation is $b: c$, or $\alpha=c /(b+c)$.

In Table 1, these exogenous parameters are $\tau=0.4, k=0.3, r=0.05, A_{0}=4000, v=0.35$, $\eta=0.5$, and $\beta=0.08$. The result shows that the payment to a bank debt is far larger than that to a bond and that the ratio of the bank debt to overall debt is more than $99 \%$. Although the debt structure is biased toward the bank debt, it is obvious from Figure 1 that a firm value attains its maximum as an inner solution. This figure plots the neighborhood of the optimum $V, b$, and $c$ of Table 1. Optimum interest payments $b^{*}$ and $c^{*}$ exist such that Equations (8) and (9) hold simultaneously. Capital structure and debt structure are optimized in that both the equations can be solved into a unique solution. What is this economic interpretation? As is often the case with traditional capital structure models, $b^{*}$ and $c^{*}$ are decided by a trade-off between the benefits of tax shields and the costs concerning bankruptcy.

As for the tax saving, there are two kinds of debt, and they substitute for each other. For example, according to DeAngelo-Masulis (1980), a non-debt tax shield like depreciation restrains the use of debt. The reason is that the non-debt tax shield is substituted into interest payments for a certain amount of overall tax shields. In other words, something which can replace interest payments restrains debt. When renegotiation or bankruptcy does not occur in our model, an interest payment to the bank debt has the same effect on the tax shield as that to the bond. Since these payments are good substitutes for each other, $b$ suppresses $c$, and vice versa.

Next, the expected bankruptcy costs are influenced by interest payments through the default probability. The interest paid on the bank debt as well as the bond has the same effect on the expected bankruptcy costs. However, the bank debt is different from the bond in that only the bank debt is renegotiable. When a firm uses the bank debt, its interest payment can be reduced as the result of renegotiation. Hence the bank debt makes the bankruptcy point increase less quickly than the bond. This means that the bank debt is more advantageous than 
Table 1 Numerical Example (without Additional Bank Costs)

parameters

\begin{tabular}{ccccccc}
\hline$\tau$ & $k$ & $r$ & $A_{0}$ & $v$ & $\eta$ & $\beta$ \\
\hline \hline 0.40 & 0.300 & 0.05 & 4000.00 & 0.35 & 0.50 & 0.08 \\
\hline
\end{tabular}

\begin{tabular}{cccccc}
$\begin{array}{c}\text { results } \\
b\end{array}$ & $c$ & $A_{S}$ & $A_{B}$ & $\theta\left(A_{S}\right)$ & $\hat{s}\left(A_{S}\right)$ \\
\hline \hline 621.7513 & 1.0794 & 2784.660 & 20.991 & 0.235 & 188.682 \\
\hline \multicolumn{7}{c}{$\left(A_{0}\right)$} & $B\left(A_{0}\right)$ & $C\left(A_{0}\right)$ & $V\left(A_{0}\right)$ & D.R. & B.D.R. \\
\hline \hline 1284.201 & 4185.224 & 19.286 & 5488.711 & 0.76603 & 0.99541 \\
\hline
\end{tabular}

note: D.R. represents the debt ratio, or $\left\{B\left(A_{0}\right)+C\left(A_{0}\right)\right\} / V\left(A_{0}\right)$. B.D.R. represents the ratio of bank debt to whole debt, or $B\left(A_{0}\right) /\left\{B\left(A_{0}\right)+C\left(A_{0}\right)\right\}$.

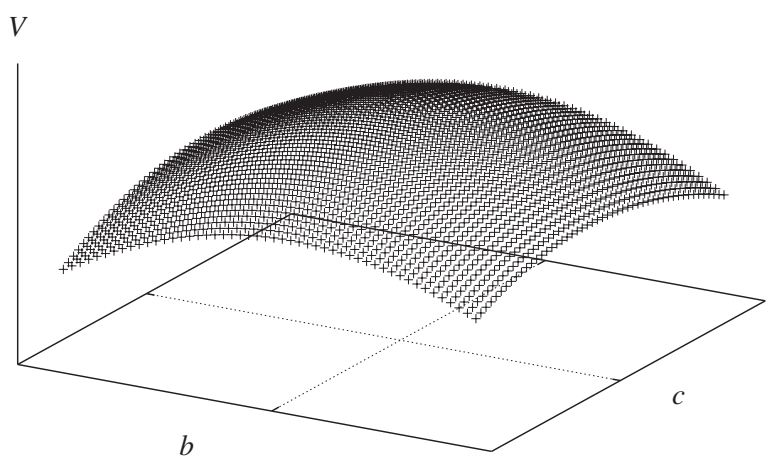

Figure 1 Firm Value, $V$, and Interest Payments, $b$ and $c$

note: This figure shows that a firm value $V$ is maximized as an inner solution in the calculation of Table 1.

the bond in terms of the trade-off between the tax shield and the bankruptcy cost.

It is notable that the renegotiation does not only benefit the bank debt but also the bond. Compared with the situation where renegotiation is impossible, renegotiability delays bankruptcy and increases probability of continuing projects, and then bondholders have a free ride on it. That is, the renegotiation with the bank avoids or delays incurring bankruptcy costs, which might be actually borne otherwise. So the bond, as well as the bank debt, also gains from the renegotiation.

Synthesizing the effects mentioned above, a firm knows the optimal interest payments from an inner solution of Equations (8) and (9), which decides its optimal capital and debt structure. Although the bank debt and the bond are similar in balancing the tax shields with the bankruptcy costs, the renegotiability gives larger advantage to the bank debt than the bond, and leads to dominance of the bank debt. It is convincing that the renegotiation benefits the bank debt far more than the bond because the bank is a participant of the renegotiation.

Our model is the same as HHL model in that a bank debt, a bond, and equity exist together. However, our model differs from HHL because the composition of the three securities is derived as an inner solution in optimization. Substantially, HHL derives it as a corner solution, and a bank debt is used as much as possible. This is because the bankruptcy point of HHL 
model is independent of the bank debt. In HHL model, renegotiation is based on the Take-itor-Leave-it game, and the bank debt has no effect on bankruptcy because shareholders get all benefit of the renegotiation. Using the bank debt gives shareholders all the benefit without any increases in expected bankruptcy costs. Then it is optimal for a firm to make as much use of the bank debt as possible.

By comparison, the use of a bank debt affects the bankruptcy point in our model. Assuming a renegotiation process as the Nash Bargaining solution, the bank debt also increases the bankruptcy point because the bank as well as shareholders retains some benefits of the renegotiation. Although the possibility of the renegotiation strongly influences the bank debt, it is also beneficial to a bond. This is because our model can decide the optimal capital and debt structure as an inner solution. ${ }^{7}$

In HHL model, the use of a bank debt is limited to such an amount that the renegotiation point is equal to firm's initial asset value. As the result, renegotiation may start just at the outset in their model. Using our numerical example, renegotiation will start immediately when the asset value is below the initial asset value $A_{0}=4000$. In other words, the numerical calculation of our model shows that the renegotiation point $A_{S}$ is about 2800, and it is improbable that the renegotiation comes about from the beginning. In reality, it would not be common that banks begin renegotiating with their clients immediately after lending. Our model is better on this aspect.

\subsubsection{An Extended Model: An Additional Bank Costs}

Although our model exhibits the existence of the optimal capital and debt structure as an inner solution, the optimal debt structure is one-sided toward the bank debt; the bank debt ratio is beyond $90 \%$. Why is the use of the bond so small? This reason is obvious from our model. In our model so far, we focus only on the renegotiation of the bank debt, which is a positive aspect, and which strongly benefits the bank debt because the bank is a participant of the renegotiation. This is why the use of the bank debt is far lager than that of the bond in the optimal debt structure. If our model is to be more practical, a negative aspect of the bank debt must be introduced into it.

What is the negative aspect of the bank debt? A lot of past studies point out that the bank debt accompanies its additional costs besides interest payments. The cost of capital on the bank itself is one example (Bolton-Freixas 2000). It is supposed that shareholders and bondholders can diversify their capital, but banks are restricted in diversifying their lending. Owing to this difference, banks force their borrowers to pay costs of capital that the banks directly bear. This brings about additional costs of the bank debt. As the firm borrows more from the bank, the cost of capital borne by the bank is supposed to increase, which adds to additional costs of the bank debt.

Although the bank debt is preferred to the bond due to the renegotiation, the renegotiation itself might have some negative impacts. For example, the chance of renegotiation aggravates the asset substitution problem, which increases the risk of firm's project (Detragiache 1994). When the firm goes worse, the bank may have an incentive to bail out it through additional lending or remission of debt. If firm's manager has already employed a large amount of the bank debt, he/she might take higher risk, expecting to renegotiate about debt reduction.

\footnotetext{
${ }^{7}$ In our model, we ignore the tax shield effect in the renegotiation region as Fan-Sundaresan (2000) does. As described at Footnote 2, we do not think that this effect is important. If the tax shield were added in the renegotiation region, it would benefit a bond, not a bank debt. The payment to the bank debt is reduced by the renegotiation, while that to the bond is not. So the tax shield in the renegotiation region has a positive effect on the bond and makes it increase slightly.
} 
Table 2 Numerical Example (with Additional Bank Costs)

\begin{tabular}{|c|c|c|c|c|c|c|c|c|}
\hline$\tau$ & $k$ & $r$ & $A_{0}$ & $v$ & $\eta$ & $\beta$ & $\xi$ & \\
\hline 0.40 & 0.300 & 0.05 & 4000.00 & 0.35 & 0.50 & 0.08 & 0.008 & \\
\hline \multicolumn{9}{|l|}{ results } \\
\hline$b$ & & $c$ & $A_{S}$ & $A_{B}$ & & $\theta\left(A_{S}\right)$ & $\hat{s}\left(A_{S}\right)$ & $M(b)$ \\
\hline \multicolumn{2}{|c|}{305.5009} & 87.5468 & 1721.815 & \multicolumn{2}{|c|}{805.072} & 0.163 & 57.312 & 10.519 \\
\hline \multicolumn{2}{|c|}{$S\left(A_{0}\right)$} & $B\left(A_{0}\right)$ & $C\left(A_{0}\right)$ & \multicolumn{2}{|c|}{$V\left(A_{0}\right)$} & D.R. & \multicolumn{2}{|c|}{ B.D.R. } \\
\hline \multicolumn{2}{|c|}{1469.067} & 2655.712 & 929.993 & \multicolumn{2}{|c|}{5054.772} & 0.70937 & \multicolumn{2}{|c|}{0.74064} \\
\hline
\end{tabular}

note: D.R. denotes the debt ratio, or $\left\{B\left(A_{0}\right)+C\left(A_{0}\right)\right\} / V\left(A_{0}\right)$. B.D.R. represents the ratio of bank debt to all kinds of debt, or $B\left(A_{0}\right) /\left\{B\left(A_{0}\right)+C\left(A_{0}\right)\right\}$.

Then, if investors anticipate it, the costs must be incurred by the firm itself.

There is another study that describes that the bank debt has additional costs because of its informational superiority. In Rajan (1992), a firm and a bank know the state the firm faces at an intermediate date, but bondholders, which he calls "Arm's-Length debt", do not. When the bank knows the state where the firm is good, then the bank requires rent against the firm. The firm anticipating this rent-extraction reduces its effort level expended at an initial date, so additional costs occur.

From the above reasons, it seems that the bank debt accompanies additional costs besides interest payments. We also analyze our extended model which explicitly considers these additional costs. For simplification, the additional costs are assumed to be a function of $b$, and expressed as $M(b)=\exp (\xi b)-1$. We also assume that $M(b)$ is directly borne by shareholders.

Since the additional cost $M(b)$ is instantaneous and reduces cash flows for all investors continuously, it affects the valuation of the firm value. When the cost exists, the firm value is rewritten from Equations (3) and (4) into

$$
\begin{aligned}
& V_{H}\left(A_{t}\right)=A_{t}+\frac{\tau(b+c)}{r}-\frac{M(b)}{r}+G_{1} A_{t}^{x}+G_{2} A_{t}^{y} \quad \text { if } A_{t}>A_{S}, \\
& V_{L}\left(A_{t}\right)=A_{t}-\frac{M(b)}{r}+G_{3} A_{t}^{x}+G_{4} A_{t}^{y} \quad \text { if } A_{S} \geq A_{t} \geq A_{B} .
\end{aligned}
$$

Terms concerning $M(b)$ are added to Equations (3) and (4) in valuation. Because the cost lowers the firm's cash flow, it decreases the firm values.

Shareholders ultimately bear this costs, so cash flows to them also decrease by $M(b)$. On the other hand, because bondholders do not bear them directly, the valuation of the bond itself is not changed. ${ }^{8}$ The bank debt does not bear the cost directly, either. However, the firm value works on the valuation of the bank debt through the Nash Bargaining renegotiation. Thus the valuation of the bank debt includes terms concerning $M(b)$. We show these specific formulas in Appendix.

Table 2 shows the result of numerical calculation when we set the same exogenous parameters as those in Table 1 . The parameter that represents the additional cost of the bank debt is $\xi=0.008$. Optimal interest payments to the bank debt and the bond are $b^{*}=305$ and $c^{*}=87.5$

\footnotetext{
${ }^{8}$ The value of the bond is indirectly affected by the additional costs through the optimal debt policy. The existence of the additional costs changes $b^{*}, c^{*}$, and $A_{B}$, which affect the bond value. Because these variables are supposed to be already given in the valuation equation, so the equation itself is not affected by $M(b)$.
} 


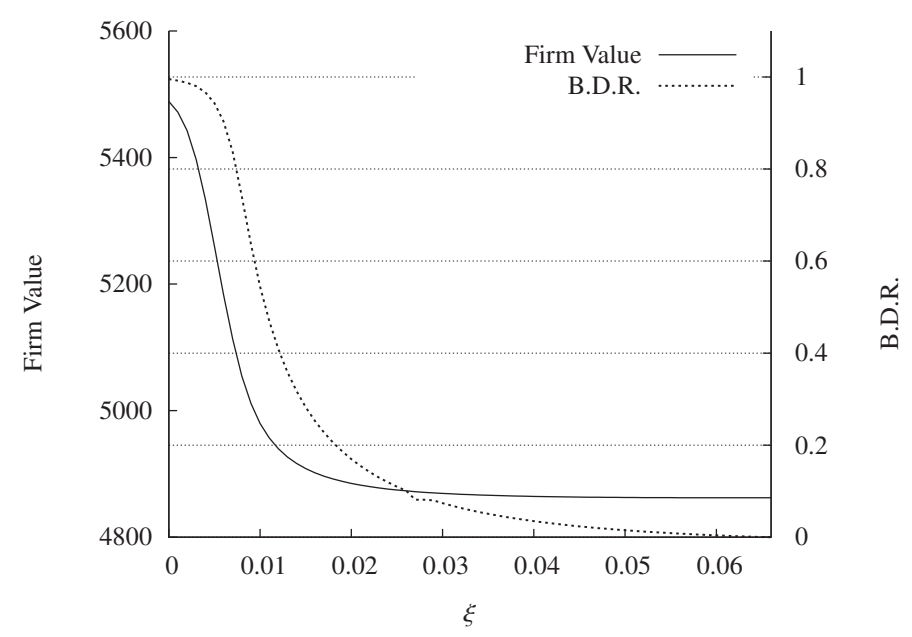

Figure 2 Changes in $\xi$

note: This plots optimal firm values and bank debt ratios (B.D.R.) when $\xi$ is changed from 0 to 0.067 by 0.001 . The same values as those of Table 2 are used in other parameters.

respectively. The renegotiation point is $A_{S}=1722$ and the bankruptcy point is $A_{B}=805$. An optimal bank debt ratio is about $74 \%$. Comparing with the former calculation, the additional cost makes the bank debt less attractive, so the firm uses more bonds while less bank debt is used. Then the bankruptcy point rises and a larger expected bankruptcy cost is borne by the firm. A firm value becomes about $V\left(A_{0}\right)=5055$ in Table 2 . Since an unlevered firm value is $A_{0}=4000$, the optimal capital structure can increase it by about $25 \%$. Then its optimal debt ratio is about $71 \%$, which seems very high in terms of actual firms. ${ }^{9}$

Figure 2 shows firm values and bank debt ratios when the parameter $\xi$ is changed. As $\xi$ is larger, the bank debt ratio gets smaller. $\xi=0$ corresponds to the result of Table 1 , so the ratio becomes close to 1 . The bank debt ratio decreases as the additional bank costs become larger. The ratio is 0 at $\xi=0.067$.

The renegotiability of the bank debt makes it more favorable than the bond. When the additional bank costs are trivial, the bank debt dominates the bond. The larger the costs are, the advantage of the renegotiation gets smaller, and the bond relatively becomes better. When the additional costs are very large, it is optimal for the firm to make as much use of the bond as possible in spite of the effect of the expected bankruptcy costs. Then the bank debt is replaced with the bond and the bank debt ratio becomes negligible.

\section{Simulation}

In Section 2, the capital structure model including the debt structure is analyzed with the numerical examples. In this section, we simulate how endogenous variables in the model change through numerical calculation. The exogenous parameters in the model are the value

\footnotetext{
${ }^{9}$ In general, it seems that optimal leverage becomes high in continuous time capital structure models. For example, Leland (1994) and Fan-Sundaresan (2000) also show high leverage in their numerical calculation.
} 
Table 3 Changes in $A_{0}$

\begin{tabular}{crrrrccc}
\hline \multicolumn{1}{c}{$A_{0}$} & \multicolumn{1}{c}{$b$} & \multicolumn{1}{c}{$c$} & \multicolumn{1}{c}{$A_{S}$} & \multicolumn{1}{c}{$A_{B}$} & $V\left(A_{0}\right)$ & D.R. & B.D.R. \\
\hline \hline 2000.00 & 31.9755 & 9.1356 & 1087.675 & 198.273 & 2616.766 & 0.74212 & 0.94004 \\
3000.00 & 285.7588 & 30.9679 & 1419.004 & 433.595 & 3849.990 & 0.71959 & 0.86980 \\
4000.00 & 305.5009 & 87.5468 & 1721.815 & 805.072 & 5054.772 & 0.70937 & 0.74064 \\
5000.00 & 304.6047 & 176.2041 & 2044.257 & 1227.186 & 6255.890 & 0.70788 & 0.60252 \\
6000.00 & 299.1672 & 272.4831 & 2370.128 & 1621.456 & 7460.923 & 0.70650 & 0.49939 \\
\hline
\end{tabular}

note: Parameters except $A_{0}$ are the same as those of Table 2. D.R. represents the debt ratio given by $\left\{B\left(A_{0}\right)+C\left(A_{0}\right)\right\} / V\left(A_{0}\right)$. B.D.R. represents the percentage of bank debt in total debt given by $B\left(A_{0}\right) /\left\{B\left(A_{0}\right)+C\left(A_{0}\right)\right\}$.

Table 4 Changes in $v$

\begin{tabular}{cccccccc}
\hline$v$ & $b$ & $c$ & $A_{S}$ & \multicolumn{1}{c}{$A_{B}$} & $V\left(A_{0}\right)$ & D.R. & B.D.R. \\
\hline \hline 0.20 & 244.1263 & 69.5713 & 1944.770 & 1085.023 & 5116.671 & 0.73359 & 0.74931 \\
0.25 & 270.8022 & 69.0762 & 1890.049 & 940.609 & 5099.894 & 0.72649 & 0.76436 \\
0.30 & 290.4794 & 75.8092 & 1810.581 & 855.964 & 5079.433 & 0.71833 & 0.75816 \\
0.35 & 305.5009 & 87.5468 & 1721.815 & 805.072 & 5054.772 & 0.70937 & 0.74064 \\
0.45 & 325.2845 & 126.2084 & 1553.278 & 765.761 & 4996.939 & 0.69198 & 0.68278 \\
\hline \multicolumn{1}{c}{ note: Parameters except $v$ are the same as those of Table 2. D.R. represents the debt ratio } \\
given by $\left\{B\left(A_{0}\right)+C\left(A_{0}\right)\right\} / V\left(A_{0}\right)$. B.D.R. represents the percentage of bank debt in \\
total debt given by $B\left(A_{0}\right) /\left\{B\left(A_{0}\right)+C\left(A_{0}\right)\right\}$.
\end{tabular}

of holding assets at the beginning $A_{0}$, a tax rate $\tau$, the ratio of bankruptcy costs $k$, volatility $v$, a riskless rate $r$, the negotiation power of shareholders $\eta$, a cash flow ratio from the assets $\beta$, and the parameter of additional bank costs $\xi$. Given these values, the model determines an optimal payment to the bank debt $b^{*}$, one to the bond $c^{*}$, a renegotiation point $A_{S}$, and a bankruptcy point $A_{B}$. Furthermore, based on these variables, a stock value $S\left(A_{0}\right)$, a bank debt value $B\left(A_{0}\right)$, a bond value $C\left(A_{0}\right)$, and a firm value $V\left(A_{0}\right)$ are derived.

\subsection{Simulation Results}

Initial values of the parameters are the same as those in Table 2. Tables 3 to 9 show how each endogenous variable reacts with a change in an exogenous parameter. Table 3 is simulation for changes in $A_{0}$. When $A_{0}$ increases, the bond is used more, and the bank debt ratio decreases. Then the bankruptcy point also increases. Hence the renegotiation of the bank debt is more favorable for a smaller firm, which tends to have the bank debt more. On the other hand, although the debt ratio is less influenced than the bank debt ratio, the former decreases with larger $A_{0}$. A firm value of the optimal capital structure increases by about $30 \%$ if $A_{0}=2000$, and it increases by about $23 \%$ if $A_{0}=6000$. So there is more advantage of using debt for a smaller firm.

Table 4 shows simulation for changes in $v$. As volatility increases, the bank debt ratio increases at first and decreases afterward. Intuitively the renegotiation seems more important when volatility gets large. In fact, interest payments to the bank debt rise with volatility. Although payments to the total debt also increase, the debt ratios get smaller since volatility itself makes the bank debt value down.

Results of simulation for changes in $r$ are Table 5. The bank debt ratio decreases with 
Table 5 Changes in $r$

\begin{tabular}{|c|c|c|c|c|c|c|c|}
\hline$r$ & $b$ & $c$ & $A_{S}$ & $A_{B}$ & $V\left(A_{0}\right)$ & D.R. & B.D.R. \\
\hline 0.01 & 271.0675 & 8.4098 & 1393.420 & 278.090 & 4953.197 & 0.66720 & 0.95317 \\
\hline 0.03 & 297.2566 & 27.9158 & 1538.694 & 469.522 & 5003.388 & 0.68062 & 0.88575 \\
\hline 0.05 & 305.5009 & 87.5468 & 1721.815 & 805.072 & 5054.772 & 0.70937 & 0.74064 \\
\hline 0.07 & 300.5938 & 171.9342 & 1890.113 & 1103.170 & 5116.483 & 0.73550 & 0.60228 \\
\hline 0.09 & 294.6289 & 260.9435 & 2028.145 & 1328.828 & 5183.170 & 0.75467 & 0.50173 \\
\hline
\end{tabular}

Table 6 Changes in $\tau$

\begin{tabular}{|c|c|c|c|c|c|c|c|}
\hline$\tau$ & $b$ & $c$ & $A_{S}$ & $A_{B}$ & $V\left(A_{0}\right)$ & D.R. & B.D.R. \\
\hline 0.35 & 301.2066 & 49.3835 & 1673.942 & 618.834 & 4844.098 & 0.68194 & 0.82767 \\
\hline 0.40 & 305.5009 & 87.5468 & 1721.815 & 805.072 & 5054.772 & 0.70937 & 0.74064 \\
\hline 0.45 & 302.6709 & 141.3797 & 1761.815 & 984.358 & 5305.167 & 0.73687 & 0.64380 \\
\hline 0.50 & 294.9300 & 208.7459 & 1787.879 & 1137.880 & 5608.127 & 0.76256 & 0.54997 \\
\hline 0.55 & 283.8567 & 290.2075 & 1800.260 & 1264.664 & 5981.202 & 0.78641 & 0.46327 \\
\hline
\end{tabular}

Table 7 Changes in $k$

\begin{tabular}{ccrcrccc}
\hline$k$ & $b$ & \multicolumn{1}{c}{$c$} & \multicolumn{1}{c}{$A_{S}$} & \multicolumn{1}{c}{$A_{B}$} & $V\left(A_{0}\right)$ & D.R. & B.D.R. \\
\hline \hline 0.100 & 297.2770 & 157.8719 & 1838.432 & 1222.598 & 5167.980 & 0.77573 & 0.63025 \\
0.300 & 305.5009 & 87.5468 & 1721.815 & 805.072 & 5054.772 & 0.70937 & 0.74064 \\
0.500 & 293.9055 & 62.7630 & 1731.551 & 564.848 & 4963.030 & 0.65596 & 0.77524 \\
0.700 & 273.4924 & 55.6831 & 1794.363 & 436.404 & 4874.436 & 0.60806 & 0.76754 \\
0.900 & 246.2686 & 56.7591 & 1864.567 & 373.160 & 4783.528 & 0.56190 & 0.73043 \\
\hline
\end{tabular}

note: Parameters except $k$ are the same as those of Table 2. D.R. represents the debt ratio given by $\left\{B\left(A_{0}\right)+C\left(A_{0}\right)\right\} / V\left(A_{0}\right)$. B.D.R. represents the percentage of bank debt in total debt given by $B\left(A_{0}\right) /\left\{B\left(A_{0}\right)+C\left(A_{0}\right)\right\}$.

a riskless rate. If a riskless rate is regarded as a discount rate, a firm is less dependent on the bank debt because an increase in a riskless rate might abate a renegotiation value in the future. But it seems strange that $r$ increases a firm value. The reason is that an increase in the riskless rate expects a growth rate of the assets to rise in the non-arbitrage condition about assets values.

Table 6 is concerning a tax rate $\tau$. A tax rate increases the debt ratio and firm values. Since the marginal effect of the tax savings is larger for a higher tax rate, a firm uses more debt. Then it makes less use of the bank debt. It is beneficial for a firm to use more debt owing to the tax shield effect when a tax rate is higher. However, if a firm has already depended on sufficient debt, the marginal cost of debt gets larger in the bank debt than the bond, which makes the percentage of the bank debt decrease.

Simulation for changes in the bankruptcy cost ratio $k$ is summarized in Table 7 . The 
Table 8 Changes in $\eta$

\begin{tabular}{cccccccc}
\hline$\eta$ & $b$ & $c$ & $A_{S}$ & $A_{B}$ & $V\left(A_{0}\right)$ & D.R. & B.D.R. \\
\hline \hline 0.00 & 326.9803 & 96.3889 & 1593.690 & 812.628 & 5180.346 & 0.76969 & 0.74521 \\
0.20 & 318.9200 & 94.0207 & 1642.860 & 815.403 & 5133.454 & 0.74792 & 0.74176 \\
0.50 & 305.5009 & 87.5468 & 1721.815 & 805.072 & 5054.772 & 0.70937 & 0.74064 \\
0.80 & 292.7680 & 72.3652 & 1808.305 & 747.532 & 4963.608 & 0.65840 & 0.75832 \\
1.00 & 287.5181 & 52.6733 & 1872.116 & 644.182 & 4895.200 & 0.61130 & 0.79893 \\
\hline
\end{tabular}

note: Parameters except $\eta$ are the same as those of Table 2. D.R. represents the debt ratio given by $\left\{B\left(A_{0}\right)+C\left(A_{0}\right)\right\} / V\left(A_{0}\right)$. B.D.R. represents the percentage of bank debt in total debt given by $B\left(A_{0}\right) /\left\{B\left(A_{0}\right)+C\left(A_{0}\right)\right\}$.

Table 9 Changes in $\beta$

\begin{tabular}{cccccccc}
\hline$\beta$ & $b$ & $c$ & \multicolumn{1}{c}{$A_{S}$} & $A_{B}$ & $V\left(A_{0}\right)$ & D.R. & B.D.R. \\
\hline \hline 0.04 & 311.1250 & 68.6294 & 2121.726 & 758.617 & 5239.728 & 0.74532 & 0.77372 \\
0.06 & 308.9748 & 75.0818 & 1897.050 & 773.396 & 5138.643 & 0.72571 & 0.76384 \\
0.08 & 305.5009 & 87.5468 & 1721.815 & 805.072 & 5054.772 & 0.70937 & 0.74064 \\
0.10 & 299.6725 & 107.6641 & 1588.548 & 851.634 & 4986.262 & 0.69715 & 0.70303 \\
0.16 & 266.4740 & 209.7954 & 1351.880 & 992.059 & 4852.326 & 0.67858 & 0.54038 \\
\hline
\end{tabular}

note: Parameters except $\beta$ are the same as those of Table 2. D.R. represents the debt ratio given by $\left\{B\left(A_{0}\right)+C\left(A_{0}\right)\right\} / V\left(A_{0}\right)$. B.D.R. represents the percentage of bank debt in total debt given by $B\left(A_{0}\right) /\left\{B\left(A_{0}\right)+C\left(A_{0}\right)\right\}$.

bankruptcy costs decrease the debt ratio and a firm value, and increase the bank debt ratio. When the bankruptcy cost parameter gets larger, the marginal expected bankruptcy costs rise with the marginal tax shield effect fixed. Hence, the optimal behavior is to decrease the debt. Then the renegotiation of the bank debt is more important. So a firm makes more use of the bank debt in order to avoid bankruptcy through the renegotiation. In fact, the bankruptcy point decreases with $k$.

Results for changes in stockholders' negotiation power $\eta$ are Table 8. As the negotiation power increases, firm values and debt ratios decrease. On the other hand, the effect of the negotiation power on the bank debt ratio is different between low $\eta$ and high $\eta$. While the bank debt ratio decreases in the case of low $\eta$, it increases in the case of high $\eta$.

Table 9 shows results of simulation for $\beta$. $\beta$ decreases both of the debt ratios and the bank debt ratios. $\beta$ is a cash flow ratio to investors and is considered as a payout ratio. Hence, this fact represents that a firm with a high payout ratio decreases the debt ratio and is less dependent on the bank debt.

\subsection{Comparison with Facts Found in Previous Studies}

The above simulation suggests what our model is like. There are many empirical studies which have pointed out many facts about capital structure. Frank-Goyal (2008) indicates some variables which are empirically robust as capital structure determinants

Our model also considers debt structure. There are few empirical studies about it not only in the U.S. but also in Japan. However, there exists empirical observation about factors for debt structure. In this section, we discuss validity of our model through comparing between observed facts in previous studies and what our model derives about capital and debt structure. 
The initial assets value $A_{0}$ in our model is regarded as firm's size. From our simulation result, a large firm has a low debt ratio for capital structure although its effect is not very strong. The simulation for debt structure shows that a large firm has a low bank debt ratio. Many studies about debt structure determinants such as Cantillo-Wright (2000), Denis-Mihov (2003), Hosono (2003), and Houston-James (1996) observe that larger firms have lower bank debt ratios and tend to use more marketable debt like a bond. Therefore, this fact is consistent with our model.

On the other hand, typical observation for capital structure is that a debt ratio has positive correlation with firm's size. Hence the effect of the size on the debt ratio in our model is contradictory to the fact. However, in terms of a static trade-off model, it is often pointed out that a debt ratio and firm's size are positively correlated because a large firm is more stable. The larger firm generally diversifies its assets, the more it stabilizes earnings and puts down default probability. In other words, it might be the stability of earnings, not the size itself, why a debt ratio has a positive relation with size. Our numerical calculation shows that volatility and a debt ratio have a negative relation. Our simulation captures this aspect in that a large firm with less volatility has a high debt ratio.

It is often observed that a tangible asset ratio has a robust factor for capital structure, where the ratio is measured as a proportion of tangible assets over total assets. Frank-Goyal (2009) finds that a debt ratio and a tangible asset ratio have positive correlation. Generally, the more tangible the assets are, the lower the bankruptcy costs are because the liquidation value of the assets is higher. In our numerical calculation, when the bankruptcy cost parameter $k$ is smaller, the debt ratio becomes higher. The degree of the change is relatively large, and this result is considered consistent with the fact.

Furthermore, some studies point out that asset tangibility has an effect on debt structure. Cantillo-Wright (2000), Houston-James (2001), and Johnson (1997) find that firms with more tangible assets tends to use bonds and their bank debt ratios are low. On the other hand, although it is not consecutive, our numerical calculation indicates that $k$ increases the bank debt ratio over plausible values of $k$, This is consistent with the fact.

In addition, Frank-Goyal (2009) empirically observes that firms paying dividends tend to have a lower debt ratio. However, there are few studies about the effect of dividends on debt structure. Houston-James (2001) points out that firms with a high payout ratio is less dependent on the bank debt. In our numerical calculation, $\beta$ represents a payout ratio to investors, and an increase in $\beta$ lowers a debt ratio and a bank debt ratio. Our results are consistent with the facts.

Finally, it is pointed out that capital structure affects debt structure. Houston-James (1996), Johnson (1997), and Denis-Mihov (2003) observes that a debt ratio is negatively correlated to a bank debt ratio. ${ }^{10}$ However, it is difficult to consistently interpret the fact in our model. In the numerical calculation, some parameters change the debt ratio and the bank debt ratio in the same direction and others change them in the opposite one. For instance, when $A_{0}$ or $\beta$ changes, the debt ratio and the bank debt ratio move in the same way. But in the case of $r$ and $\tau$, they move contrariwise. Therefore, our model does not always has a negative correlation between the debt ratio and the bank debt ratio.

\footnotetext{
${ }^{10}$ It is considered that capital structure and debt structure are determined simultaneously. Therefore, an endogenous problem in regression arises when a debt ratio is used as an explanatory variable. Johnson (1997) overcomes the problem, separating a debt ratio into two parts determined exogenously and endogenously. Specifically, he regresses a debt ratio on independent variables such as firm's size and age, and uses its residual as the exogenously determined part.
} 


\section{Fixed Bankruptcy and Renegotiation Points}

In the model described above, we assumed that shareholders could choose the bankruptcy and renegotiation points without restriction. As a result, they could fix the points that maximize the equity value. However, what occurs to the capital structure and the debt structure of the firm if the shareholders are prevented from choosing these points? In this section, we consider the case that the bankruptcy and renegotiation points are given in advance.

\subsection{How to Decide the Bankruptcy and Renegotiation Points}

In this section, unlike Section 2, the bankruptcy and renegotiation points are defined as follows. First, as to the renegotiation point, we define it as such a level of the state variable that firm's earnings fall below the promised payments. Shareholders must pay for the interest payments $b+c$ and bank debt additional costs $M(b)$ from cash flows $\beta A_{t}$ generated by firm's assets. Hence, if the cash flows from the firm's assets run short, the shareholders have to request reduction or exemption of the interest payments by renegotiating with a bank. Considering the tax shields of the interest payments, the renegotiation point is defined as follow:

$$
A_{S}=\frac{(1-\tau)(b+c)+M(b)}{\beta} .
$$

In the area that the value of assets $A_{t}$ is lower than $A_{S}$, the renegotiation is carried out between the shareholders and the bank, and interest payments to the bank is reduced to $\hat{s}\left(A_{t}\right)$.

In this case, there is a probability that the shareholders pay the promised payments by issuing new shares. In order to see this, consider the situation that the shareholders can issue new shares to pay for the payments. If the renegotiation is not carried out, the equity value is $S_{H}\left(A_{t}\right)$. If the existing shareholders raise funds from new shareholders whose shares are $(1-\chi)$ in order to cover the deficit, then $(1-\chi) S_{H}\left(A_{t}\right)=(1-\tau)(b+c)+M(b)-\beta A_{t}$ holds.

The value of the existing shareholders is diluted to $\chi S_{H}\left(A_{t}\right)$. Since $\chi S_{H}\left(A_{t}\right)=S_{H}\left(A_{t}\right)-$ $(1-\chi) S_{H}\left(A_{t}\right), \chi S_{H}\left(A_{t}\right)=S_{H}\left(A_{t}\right)+\beta A_{t}-(1-\tau)(b+c)-M(b)$ is obtained. On the other hand, if the existing shareholders renegotiate with the bank without issuing new shares, their value is $S_{L}\left(A_{t}\right)$. When $\chi S_{H}\left(A_{t}\right)>S_{L}\left(A_{t}\right)$, the existing shareholders choose to issue new shares. When $\chi S_{H}\left(A_{t}\right)<S_{L}\left(A_{t}\right)$, the renegotiation is favorable. So in the renegotiation point, $\chi S_{H}\left(A_{S}\right)=$ $S_{L}\left(A_{S}\right)$ is satisfied, that is, $S_{H}\left(A_{S}\right)+\beta A_{S}-(1-\tau)(b+c)-M(b)=S_{L}\left(A_{S}\right)$ holds. Recalling $S_{H}\left(A_{S}\right)=$ $S_{L}\left(A_{S}\right)$ as the value mating condition, the renegotiation point is given as Equation (10).

Next, we consider the bankruptcy point. Intuitively, the firm will become bankrupt in the situation that the firm's earnings go from bad to worse and that the shareholders cannot pay for even the renegotiated interest payments. Thus, the bankruptcy point is defined as such a level of the state variable that the firm's cash flow $\beta A_{t}$ is below $\hat{s}\left(A_{t}\right)+c$. That is, $\beta A_{B}=\hat{s}\left(A_{B}\right)+c$. Using $\hat{s}\left(A_{t}\right)$ derived from $B_{L}\left(A_{t}\right),{ }^{11}{ }^{12}$

$$
A_{B}=\frac{c+M(b)}{\beta\{1-(1-\alpha)(1-k)\}} .
$$

When the value of assets $A_{t}$ reaches $A_{B}$, the firm goes bankrupt and is liquidated.

These renegotiation and bankruptcy points are quite different from those derived from the maximization condition or the smooth pasting condition. In theory, the former is inferior

\footnotetext{
${ }^{11}$ The formula of $\hat{s}\left(A_{t}\right)$ is indicated in Appendix.

${ }^{12}$ In the case that the shareholders can issue new shares, the same argument as above holds.
} 
Table 10 Numerical Example: Fixed Bankruptcy and Renegotiation Points parameters

\begin{tabular}{|c|c|c|c|c|c|c|c|}
\hline$\tau$ & $k$ & $r$ & $A_{0}$ & $v$ & $\eta$ & $\beta$ & $\xi$ \\
\hline 0.40 & 0.300 & 0.05 & 4000.00 & 0.35 & 0.50 & 0.08 & 0.03 \\
\hline \multicolumn{8}{|l|}{ results } \\
\hline$b$ & \multicolumn{2}{|c|}{$c$} & $A_{S}$ & $A_{B}$ & $\theta\left(A_{S}\right)$ & $\hat{s}\left(A_{S}\right)$ & $M(b$ \\
\hline 63.7322 & \multicolumn{2}{|c|}{0.3614} & 552.782 & 252.009 & 0.145 & 34.438 & 5.76 \\
\hline$S\left(A_{0}\right)$ & \multicolumn{2}{|c|}{$B\left(A_{0}\right)$} & $C\left(A_{0}\right)$ & $V\left(A_{0}\right)$ & D.R. & \multicolumn{2}{|c|}{ B.D.R. } \\
\hline 3292.007 & \multicolumn{2}{|c|}{925.462} & 5.309 & 4222.778 & 0.22042 & \multicolumn{2}{|c|}{0.99430} \\
\hline
\end{tabular}

note: D.R. denotes the debt ratio, or $\left\{B\left(A_{0}\right)+C\left(A_{0}\right)\right\} / V\left(A_{0}\right)$. B.D.R. represents the ratio of bank debt to all kinds of debt, or $B\left(A_{0}\right) /\left\{B\left(A_{0}\right)+C\left(A_{0}\right)\right\}$.

to the latter in terms of a firm value. But it is practical that a bank exempts a borrower from incurring debt services when the borrower cannot fulfill his/her obligation. In addition, the limited liability of shareholders forces a firm to fall into bankruptcy when the cash flows to the shareholders are below zero.

Deciding the renegotiation and bankruptcy points in this way, we can calculate the interest payments, $b$ and $c$, that maximize the firm value. Then, substituting these $b$ and $c$ into the security value equations, each security is evaluated.

\subsection{A Numerical Example}

When the renegotiation and bankruptcy points are determined as mentioned above, what becomes of capital structure? Here, in the same way as Section 2.3 , we analyze the capital structure and the debt structure by numerical calculation. The exogenous parameters are the same as those in Section 2.3: $\tau=0.4, r=0.05, A_{0}=4000, v=0.35, \eta=0.5$ and $\beta=0.08$. The parameter for the additional bank cost is given $\xi=0.03$.

Table 10 presents calculation results under these parameters. In the case that the renegotiation and bankruptcy points are fixed, the debt ratio is very low. In this calculation, the debt ratio is about $22 \%$. From the bank debt ratio, the bank debt is used in $99 \%$ of total debt. It is also characteristic that the increase in the firm value is about $5 \%$ by using debt. This results from the reduction of the tax shield owing to a decrease in the optimal debt ratio.

However, this calculation is lack of stability, unlike the case that the bankruptcy and renegotiation points are derived from the maximization conditions. In particular, if the additional bank debt cost gets lower slightly, the debt ratio becomes $100 \%$, and if the additional cost gets higher slightly, the debt ratio suddenly drops to $0 \%$. Therefore, setting these points arbitrarily raises defects of the model and causes the lack of stability.

\section{Conclusion}

In our paper, we propose the model that discusses capital structure and debt structure at the same time, and determines the proportion of a bank debt, a bond and equity in terms of the trade-off theory. There are many differences between the bank debt and the bond. In this study, we focus on the possibility of renegotiation when a firm goes into deterioration in 
earnings. The bank debt, which is owed to a few specific lenders, may be easier to renegotiate than the bond held by public and unspecific creditors.

Hackbarth-Hennessy-Leland (2007), which discusses the debt structure as well as capital structure, has the drawback that proportions of the bank debt, the bond, and the equity are determined as a corner solution. Their model makes the renegotiation come about at a initial time. To the contrary, our model decides these proportions from an optimal inner solution. This result contrasts with Hackbarth-Hennessy-Leland (2007) in that the renegotiation is not implemented at an initial time.

Although we got the inner solution of the optimal conditions, the numerical calculation in our basic model shows that the bank debt occupies more than 90 percent of total debt. The reason why the bank debt is dominant is that the renegotiation benefits the bank, but not bondholders. On the other hand, many previous studies pointed out that a bank debt accompanies some additional costs. In our study, a firm is assumed to incurs the additional costs with using the bank debt, and our model is extended into this assumption. As the result, since the bank debt becomes less advantageous, the bonds is used more. In our numerical calculation based on the model with the additional bank debt costs, the debt structure achieves a more realistic aspect.

In our model, the bankruptcy and renegotiation points were derived from the maximization conditions of the equity value, which is a general method in continuous time capital structure models. In other words, we implicitly supposed that shareholders could choose these points without restriction. In the last section of this study, we consider the case where these points are given in a intuitive way, assuming that the shareholders cannot choose them freely. Under this assumption, we indicated that the optimal debt ratio is very low in our simulation. However, the result of the calculation lacks stability, unlike the case of the maximization conditions. Therefore, setting these points arbitrarily may cause defects of the model.

By the way, although our model can achieve a realistic bank debt ratio as debt structure, it is impossible to realize realistic capital structure. This is the common problem in continuous time capital structure models; in many previous studies, debt ratios predicted by models are far larger than actual ones. One of the possible reasons is that expected bankruptcy costs are very small relative to the benefit of the tax shield of debt. Using debt may accompany something negative other than the bankruptcy costs. For instance, Morellec (2004) introduces an agency problem between investors and a manager into his trade-off model, and presents realistic debt ratios. ${ }^{13}$ It remains possible that our model is improved by introducing something accompanied by debt. This is another challenge in our future research.

\section{Appendix}

\section{Firm Value Formulas}

A cash flow to all investors is $\beta A_{t}+\tau(b+c)-M(b)$ for $A_{t}>A_{S}$. Assuming that there is no tax shield of debt under renegotiation, a cash flow is $\beta A_{t}-M(b)$ for $A_{S} \geq A_{t} \geq A_{B}$. Hence, a firm value $V\left(A_{t}\right)$ is represented by the following equations.

\footnotetext{
${ }^{13}$ In the model of Morellec (2004), because the objective function of a manager who decides capital structure is not to maximize the firm value, its capital structure dose not maximize the firm value. On the other hand, a trade-off model between costs and benefits of debt determines the capital structure, maximizing the firm value. So both models are a quite different framework.
} 


$$
\begin{aligned}
& V_{H}\left(A_{t}\right)=A_{t}+\frac{\tau(b+c)}{r}-\frac{M(b)}{r}+G_{1} A_{t}^{x}+G_{2} A_{t}^{y} \quad \text { if } A_{t}>A_{S} \\
& V_{L}\left(A_{t}\right)=A_{t}-\frac{M(b)}{r}+G_{3} A_{t}^{x}+G_{4} A_{t}^{y} \quad \text { if } A_{S} \geq A_{t} \geq A_{B}
\end{aligned}
$$

$x$ and $y$ are defined in Equation (2). Boundary conditions of the next four equations are imposed.

$$
\begin{aligned}
V_{H}\left(A_{t}\right) & =A_{t}+\frac{\tau(b+c)}{r}-\frac{M(b)}{r} \quad \text { if } A_{t} \gg A_{S} \\
\lim _{A_{t} \downarrow A_{S}} V_{H}\left(A_{t}\right) & =\lim _{A_{t} \uparrow A_{S}} V_{L}\left(A_{t}\right) \\
\lim _{A_{t} \downarrow A_{B}} V_{L}\left(A_{t}\right) & =(1-k) A_{B} \\
\lim _{A_{t} \downarrow A_{S}} \frac{\partial V_{H}\left(A_{t}\right)}{\partial A_{t}} & =\lim _{A_{t} \uparrow A_{S}} \frac{\partial V_{L}\left(A_{t}\right)}{\partial A_{t}}
\end{aligned}
$$

Arbitrary constants are specified by the above conditions, and the firm values, $V_{H}\left(A_{t}\right)$ and $V_{L}\left(A_{t}\right)$, are calculated as follows.

$$
\begin{aligned}
V_{H}\left(A_{t}\right)= & A_{t}+\frac{\tau(b+c)}{r}-\left\{1-\left(\frac{A_{t}}{A_{B}}\right)^{y}\right\} \frac{M(b)}{r}-\frac{x}{x-y} \frac{\tau(b+c)}{r}\left(\frac{A_{t}}{A_{S}}\right)^{y} \\
& +\frac{y}{x-y} \frac{\tau(b+c)}{r}\left(\frac{A_{B}}{A_{S}}\right)^{x}\left(\frac{A_{t}}{A_{B}}\right)^{y}-k A_{B}\left(\frac{A_{t}}{A_{B}}\right)^{y} \\
V_{L}\left(A_{t}\right)= & A_{t}-\left\{1-\left(\frac{A_{t}}{A_{B}}\right)^{y}\right\} \frac{M(b)}{r}-\frac{y}{x-y} \frac{\tau(b+c)}{r}\left(\frac{A_{t}}{A_{S}}\right)^{x} \\
& +\frac{y}{x-y} \frac{\tau(b+c)}{r}\left(\frac{A_{B}}{A_{S}}\right)^{x}\left(\frac{A_{t}}{A_{B}}\right)^{y}-k A_{B}\left(\frac{A_{t}}{A_{B}}\right)^{y}
\end{aligned}
$$

\section{A Bond Value Formula}

As long as $A_{t} \geq A_{B}$, bonds generate a cash flow $c$. A bond is valuated as $C\left(A_{t}\right)$.

$$
C\left(A_{t}\right)=\frac{c}{r}+H_{1} A_{t}^{x}+H_{2} A_{t}^{y}
$$

Boundary conditions of the following two equations are imposed.

$$
\begin{aligned}
C\left(A_{t}\right) & =\frac{c}{r} \quad \text { if } A_{t} \gg A_{B} \\
\lim _{A_{t} \downarrow A_{B}} C\left(A_{t}\right) & =\alpha(1-k) A_{B}
\end{aligned}
$$

From these conditions, $C\left(A_{t}\right)$ is calculated as follows.

$$
C\left(A_{t}\right)=\left\{1-\left(\frac{A_{t}}{A_{B}}\right)^{y}\right\} \frac{c}{r}+\alpha(1-k) A_{B}\left(\frac{A_{t}}{A_{B}}\right)^{y}
$$

The first term represents the present value of the cash flow $c$ as long as the firm does not go bankrupt, and the second is the present value of $\alpha(1-k) A_{B}$ obtained in the case of bankruptcy.

\section{Bank Debt Value Formulas}

Interest to the bank debt under renegotiation is paid $\hat{s}\left(A_{t}\right)$. Cash flows to the bank debt are $b$ for $A_{t}>A_{S}$ and $\hat{s}\left(A_{t}\right)$ for $A_{S} \geq A_{t} \geq A_{B}$. 
First, in the case of $A_{t} \geq A_{S}$, a bank debt value $B_{H}\left(A_{t}\right)$ is represented as:

$$
B_{H}\left(A_{t}\right)=\frac{b}{r}+L_{1} A_{t}^{x}+L_{2} A_{t}^{y} \quad \text { if } A_{t}>A_{S} .
$$

Boundary conditions of the following two equations are imposed.

$$
\begin{aligned}
B_{H}\left(A_{t}\right) & =\frac{b}{r} \quad \text { if } A_{t} \gg A_{S} \\
\lim _{A_{t} \downarrow A_{S}} B_{H}\left(A_{t}\right) & =\left\{1-\theta^{*}\right\}\left\{V\left(A_{S}\right)-C\left(A_{S}\right)\right\}
\end{aligned}
$$

From these conditions, the bank debt value $B_{H}\left(A_{t}\right)$ is calculated as follows.

$$
\begin{aligned}
B_{H}\left(A_{t}\right)= & \left\{1-\left(\frac{A_{t}}{A_{S}}\right)^{y}\right\} \frac{b}{r}+\eta(1-\alpha)(1-k) A_{S}\left(\frac{A_{t}}{A_{S}}\right)^{y}+(1-\eta)\left[A_{S}\right. \\
& -\left\{1-\left(\frac{A_{S}}{A_{B}}\right)^{y}\right\} \frac{M(b)}{r}-\frac{y}{x-y} \frac{\tau(b+c)}{r}+\frac{y}{x-y} \frac{\tau(b+c)}{r}\left(\frac{A_{B}}{A_{S}}\right)^{x-y} \\
& \left.-k A_{B}\left(\frac{A_{S}}{A_{B}}\right)^{y}-\left\{1-\left(\frac{A_{S}}{A_{B}}\right)^{y}\right\} \frac{c}{r}-\alpha(1-k) A_{B}\left(\frac{A_{S}}{A_{B}}\right)^{y}\right]\left(\frac{A_{t}}{A_{S}}\right)^{y}
\end{aligned}
$$

In the case of $A_{S} \geq A_{t} \geq A_{B}, B_{L}=\left(1-\theta^{*}\right)\left\{V\left(A_{t}\right)-C\left(A_{t}\right)\right\}$ must be satisfied by the result of the renegotiation. Thus, $B_{L}\left(A_{t}\right)$ is calculated as next.

$$
\begin{aligned}
B_{L}\left(A_{t}\right)= & (1-\eta)\left[A_{t}-\left\{1-\left(\frac{A_{t}}{A_{B}}\right)^{y}\right\} \frac{M(b)}{r}-\frac{y}{x-y} \frac{\tau(b+c)}{r}\left(\frac{A_{t}}{A_{S}}\right)^{x}+\right. \\
& \frac{y}{x-y} \frac{\tau(b+c)}{r}\left(\frac{A_{B}}{A_{S}}\right)^{x}\left(\frac{A_{t}}{A_{B}}\right)^{y}-k A_{B}\left(\frac{A_{t}}{A_{B}}\right)^{y}-\left\{1-\left(\frac{A_{t}}{A_{B}}\right)^{y}\right\} \frac{c}{r} \\
& \left.-\alpha(1-k) A_{B}\left(\frac{A_{t}}{A_{B}}\right)^{y}\right]+\eta(1-\alpha)(1-k) A_{t}
\end{aligned}
$$

The equilibrium condition for $A_{S} \geq A_{t} \geq A_{B}$ is:

$$
\frac{\partial B_{L}\left(A_{t}\right)}{\partial A_{t}}(r-\beta) A_{t}+\frac{1}{2} \frac{\partial^{2} B_{L}\left(A_{t}\right)}{\partial A_{t}^{2}} v^{2} A_{t}^{2}-r B_{L}\left(A_{t}\right)+\hat{s}\left(A_{t}\right)=0 \quad \text { if } A_{S} \geq A_{t} \geq A_{B} .
$$

Substituting $B_{L}\left(A_{t}\right)$ into this equation, we obtain the following. ${ }^{14}$

$$
\hat{s}\left(A_{t}\right)=\{(1-\eta)+\eta(1-\alpha)(1-k)\} \beta A_{t}-(1-\eta)\{c+M(b)\}
$$

\section{Equity Value Formulas}

For $A_{S} \geq A_{t} \geq A_{B}$, an equity value is $\theta^{*}\left\{V\left(A_{t}\right)-C\left(A_{t}\right)\right\}$ through the renegotiation. The equity value in this area is denoted by $S_{L}\left(A_{t}\right)$, which is calculated as follows.

$$
\begin{aligned}
S_{L}\left(A_{t}\right)= & \eta\left[\{1-(1-\alpha)(1-k)\} A_{t}-\left\{1-\left(\frac{A_{t}}{A_{B}}\right)^{y}\right\} \frac{M(b)}{r}-\frac{y}{x-y} \frac{\tau(b+c)}{r}\left(\frac{A_{t}}{A_{S}}\right)^{x}\right. \\
& +\frac{y}{x-y} \frac{\tau(b+c)}{r}\left(\frac{A_{B}}{A_{S}}\right)^{x}\left(\frac{A_{t}}{A_{B}}\right)^{y}-k A_{B}\left(\frac{A_{t}}{A_{B}}\right)^{y} \\
& \left.-\left\{1-\left(\frac{A_{t}}{A_{B}}\right)^{y}\right\} \frac{c}{r}-\alpha(1-k) A_{B}\left(\frac{A_{t}}{A_{B}}\right)^{y}\right]
\end{aligned}
$$

\footnotetext{
${ }^{14}$ In our numerical calculation, $\hat{s}$ is not always lower than the promised interest $b$.
} 
On the other hand, since a cash flow to shareholders is $\beta A_{t}-(1-\tau)(b+c)-M(b)$ for $A_{t}>A_{S}$, an equity value $S_{H}\left(A_{t}\right)$ is represented by the following equation.

$$
S_{H}\left(A_{t}\right)=A_{t}-\frac{(1-\tau)(b+c)}{r}-\frac{M(b)}{r}+J_{1} A_{t}^{x}+J_{2} A_{t}^{y} \quad \text { if } A_{t}>A_{S}
$$

Boundary conditions of the following two equations are imposed.

$$
\begin{aligned}
S_{H}\left(A_{t}\right) & =A_{t}-\frac{(1-\tau)(b+c)}{r}-\frac{M(b)}{r} \quad \text { if } A_{t} \gg A_{S} \\
\lim _{A_{t} \downarrow A_{S}} S_{H}\left(A_{t}\right) & =\theta^{*}\left\{V\left(A_{S}\right)-C\left(A_{S}\right)\right\}
\end{aligned}
$$

From these conditions, $S_{H}\left(A_{t}\right)$ is calculated as next.

$$
\begin{aligned}
S_{H}\left(A_{t}\right)= & A_{t}-\left\{1-\left(\frac{A_{t}}{A_{S}}\right)^{y}\right\} \frac{(1-\tau)(b+c)}{r}-\left\{1-\left(\frac{A_{t}}{A_{S}}\right)^{y}\right\} \frac{M(b)}{r} \\
& -\left[\{(1-\eta)+\eta(1-\alpha)(1-k)\} A_{S}+\eta\left\{1-\left(\frac{A_{S}}{A_{B}}\right)^{y}\right\} \frac{M(b)}{r}\right. \\
& +\eta \frac{y}{x-y} \frac{\tau(b+c)}{r}-\eta \frac{y}{x-y} \frac{\tau(b+c)}{r}\left(\frac{A_{B}}{A_{S}}\right)^{x-y}+\eta k A_{B}\left(\frac{A_{S}}{A_{B}}\right)^{y} \\
& \left.+\eta\left\{1-\left(\frac{A_{S}}{A_{B}}\right)^{y}\right\} \frac{c}{r}+\eta \alpha(1-k) A_{B}\left(\frac{A_{S}}{A_{B}}\right)^{y}\right]\left(\frac{A_{t}}{A_{S}}\right)^{y}
\end{aligned}
$$

\section{Renegotiation and Bankruptcy Points}

Renegotiation and bankruptcy points are derived from the conditions to maximize the equity values.

$$
\begin{aligned}
& \frac{\partial S_{H}}{\partial A_{S}}=0 \\
& \frac{\partial S_{L}}{\partial A_{B}}=0
\end{aligned}
$$

From these, we obtain the following equations with which $A_{S}$ and $A_{B}$ are satisfied.

$$
\begin{aligned}
& \eta \frac{x y}{x-y} \frac{\tau(b+c)}{r}\left(\frac{A_{B}}{A_{S}}\right)^{x-y}+\{(1-\eta)(1-y)+\eta(1-y)(1-\alpha)(1-k)\} A_{S} \\
&+y \frac{(1-\tau)(b+c)}{r}+y(1-\eta) \frac{M(b)}{r}-\eta \frac{y^{2}}{x-y} \frac{\tau(b+c)}{r}-\eta y \frac{c}{r}=0 \\
& y \frac{\tau(b+c)}{r}\left(\frac{A_{B}}{A_{S}}\right)^{x}-(1-y)\{k+\alpha(1-k)\} A_{B}-y \frac{M(b)}{r}-y \frac{c}{r}=0
\end{aligned}
$$

Hence, we can get $A_{S}$ and $A_{B}$ by solving the simultaneous equations.

\section{References}

[1] Black, F., and M. Scholes (1973) "The Pricing of Options and Corporate Liabilities," Journal of Political Economy, Vol.81, No.3, pp.637-654.

[2] Black, F., and J. C. Cox (1976) "Valuing Corporate Securities: Some Effects of Bond Indenture Provisions," Journal of Finance, Vol.31, No.2, pp.351-367. 
[3] Bolton, P., and X. Freixas (2000) "Equity, Bonds, and Bank Debt: Capital Structure and Financial Market Equilibrium under Asymmetric Information,” Journal of Political Economy, Vol.108, No.2, pp.324-351.

[4] Cantillo, M., and J. Wright (2000) "How Do Firms Choose Their Lenders? An Empirical Investigation,” Review of Financial Studies, Vol.13, No.1, pp.155-189.

[5] DeAngelo, H., and R. W. Masulis (1980) "Optimal Capital Structure under Corporate and Personal Taxation,” Journal of Financial Economics, Vol.8, No.1, pp.3-29.

[6] Denis, D., and V. Mihov (2003) "The Choice among Bank Debt, Non-bank Private Debt, and Public Debt: Evidence from New Corporate Borrowings," Journal of Financial Economics, Vol.70, No.1, pp.3-28.

[7] Detragiache, E. (1994) "Public versus Private Borrowing: A Theory with Implications for Bankruptcy Reform," Journal of Financial Intermediation, Vol.3, No.4, pp.327-354.

[8] Dixit, A. (1993) The Art of Smooth Pasting, Harwood Academic Pub.

[9] Fan, H., and S. M. Sundaresan (2000) "Debt Valuation, Renegotiation, and Optimal Dividend Policy,” Review of Financial Studies, Vol.13, No.4, pp.1057-1099.

[10] Frank, M., and V. Goyal (2008) “Trade-off and Pecking Order Theories of Debt,” in B. Eckbo (ed.), Handbook of Corporate Finance: Empirical Corporate Finance, Vol.2, North-Holland.

[11] Frank, M., and V. Goyal (2009) "Capital Structure Decisions: Which Factors Are Reliably Important?” Financial Management, Vol.38, No.1, pp.1-37.

[12] Goldstein, R., N. Ju, and H. Leland (2001) "An EBIT-Based Model of Dynamic Capital Structure," Journal of Business, Vol.74, No.4, pp.483-512.

[13] Hackbarth, D., C. Hennessy, and H. Leland (2007) "Can the Trade-off Theory Explain Debt Structure?” Review of Financial Studies, Vol.20, No.5, pp.1389-1428.

[14] Hackbarth, D., J. Miao, and E. Morellec (2006) "Capital Structure, Credit Risk, and Macroeconomic Conditions," Journal of Financial Economics, Vol.82, No.3, pp.519-550.

[15] Hosono, K. (2003) "Growth Opportunities, Collateral and Debt Structure: The Case of the Japanese Machine Manufacturing Firms," Japan and the World Economy, Vol.15, No.3, pp.275297.

[16] Houston, J., and C. James (1996) "Bank Information Monopolies and the Mix of Private and Public Debt Claims," Journal of Finance, Vol.51, No.5, pp.1863-1889.

[17] Houston, J., and C. James (2001) "Do Relationships Have Limits? Banking Relationships, Financial Constraints, and Investment,” Journal of Business, Vol.74, No.3, pp.347-374.

[18] Johnson, S. (1997) "An Empirical Analysis of the Determinants of Corporate Debt Ownership Structure," Journal of Financial and Quantitative Analysis, Vol.32, No.1, pp.47-69.

[19] Ju, N., R. Parrino, A. M. Poteshman, and M. S. Weisbach (2005) "Horses and Rabbits? Trade-Off Theory and Optimal Capital Structure," Journal of Financial and Quantitative Analysis, Vol.40, No.2, pp.259-281.

[20] Leland, H. (1994) “Corporate Debt Value, Bond Covenants, and Optimal Capital Structure,” Journal of Finance, Vol.49, No.4, pp.1213-1252.

[21] Leland, H. (1998) “Agency Costs, Risk Management, and Capital Structure,” Journal of Finance, Vol.53, No.4, pp.1213-1243.

[22] Leland, H., and K. B. Toft (1996) "Optimal Capital Structure, Endogenous Bankruptcy, and the Term Structure of Credit Spreads,” Journal of Finance, Vol.51, No.3, pp.987-1019.

[23] MellaBarral, P. (1999) “The Dynamics of Default and Debt Reorganization," Review of Financial Studies, Vol.12, No.3, pp.535-578.

[24] MellaBarral, P., and W. Perraudin (1997) "Strategic Debt Service," Journal of Finance, Vol.52, No.2, pp.531-556. 
[25] Morellec, E. (2004) “Can Managerial Discretion Explain Observed Leverage Ratios?” Review of Financial Studies, Vol.17, No.1, pp.257-294.

[26] Parrino, R., A. M. Poteshman, and M. S. Weisbach (2005) "Measuring Investment Distortions when Risk-Averse Managers Decide Whether to Undertake Risky Projects," Financial Management, Vol.34, No.1, pp.21-60.

[27] Rajan, R. G. (1992) "Insiders and Outsiders: The Choice between Informed and Arm's-Length Debt,” Journal of Finance, Vol.47, No.4, pp.1367-1400. 